\title{
Process InNOVATION IN SERVICE SECTOR MATCHING INDUSTRY 4.0 ENVIRONMENT
}

\author{
Emil Vacík \& Miroslav Špaček
}
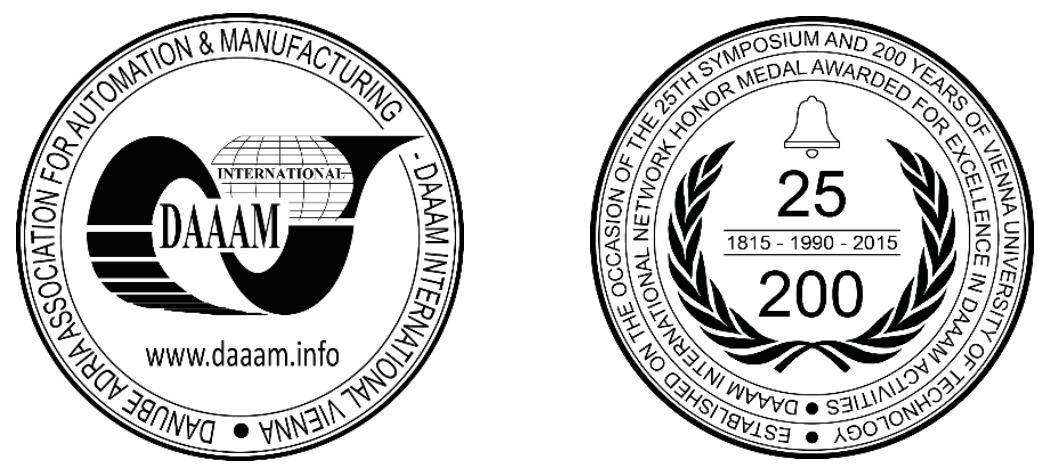

This Publication has to be referred as: Vacik, E[mil] \& Spacek, M[iroslav] (2018). Process Innovation in Service Sector Matching Industry 4.0 Environment, Proceedings of the 29th DAAAM International Symposium, pp.0352-0360, B. Katalinic (Ed.), Published by DAAAM International, ISBN 978-3-902734-20-4, ISSN 1726-9679, Vienna, Austria DOI: $10.2507 / 29$ th.daaam.proceedings.051

\begin{abstract}
In Industry 4.0 era two types of innovative development are receiving more attention: service innovation and industrial big data. The main outcome of the paper is a normative model design of decision-making on service innovation concerning outsourcing. This model combines both financial and non-financial criteria. The model also helps managers better understand the value engineering nature of outsourcing and offers clear and understandable normative decisionmaking model. The research, which was completed in 2017, was specifically based on questionnaire survey which was performed among mid-level management in the Czech and Slovak Republic. In total 89 companies were subjected to survey. This survey was complemented by contextual interviews with selected maintenance managers. The research confirmed the firms were not experienced enough to predict the future role of outsourcing matching organizational changes in Industry 4.0 environment. The literature review proved, that not similar model hasn't been presented yet. The model was practically verified on the pattern of mid-sized company. Based on research outcomes the examination of maintenance outsourcing was conducted in production, service and trading sector. Statistical significance of differences in the perception of outsourcing was tested by calculation of $\chi$-squared test.
\end{abstract}

Keywords: Industry 4.0; innovation; outsourcing; normative model

\section{Introduction}

Work on the reviewed literature, it is clear that the Industry 4.0 philosophy becomes current reality, which may considerable change existing paradigm of production processes organization. The Industry 4.0 philosophy is of the complex character involving product characteristics, processes, human factor, customer thinking and behaviour as well as the technical platform. On the base of learned information it is clear that possible impact of assumed changes have not been analysed in exhaustive way.

Contemporary innovation management probably does not sufficiently reflect demands of Industry 4.0 process. It is provable that innovation strategies as a one of the basic tools of this philosophy are complex ones (they involve products, processes, Business models, knowledge management, job competences, Big Data, controlling etc.), although particular innovation decisions to be made are independent. 
Therefore, it is necessary to follow properly effectiveness of innovation employment in new environment, which arise not continuously. It is necessary to confirm, if contemporary innovation management methods and accesses are in accordance with the future paradigm and when gaps in this way occur, it is necessary immediately design new methods and verify new normative models which will ensure the transformation of innovation strategy into value creating drivers. To cover such gap, the authors tried to ascertain firms' management demand for having a tool, which would be able to support their innovative behaviour and decision-making procedures supporting effective service ensuring in the environment of changes of Industry 4.0. Normative decision-making model, which is proposed in this paper, helps the company facilitate decision processes and supports shareholders value creation.

The normative model deals with service outsourcing which represents specific type of organizational innovation. The paper examined the penetration of service maintenance outsourcing in the Czech and Slovak Republic. According to literature review very little empirical research has been conducted in this area [13]. The examination of maintenance outsourcing principles was conducted in production, service and trading sector.

\section{Theoretical background}

Industry 4.0 is the intelligent real-time, horizontal and vertical integration of humans and machines with objects and information and communication technology systems (digitalization) to enable a flexible and dynamic management of complex systems [4]. Industry 4.0 should be considered in the category of complex systems, and like any complex system, according to the principle of indeterminacy, it cannot be ever fully understood. Uncertainty is the "new normal" in today's fast-changing times [21]. Industry 4.0 involves three, not fully defined phenomena, which prevent create simple deterministic models that would simulate a future development of the Fourth Industrial revolution. These phenomena are: (1) universal digitization, (2) increasingly implemented disruptive technological innovations, (3) the achievement of such a developed machine that gain the ability to autonomous behaviour through the use of controlling artificial intelligence [10].

Over past decade innovation was put into spotlight because of its potential to provide companies with various economic benefits. Tidd, Bessant \& Pavitt [22] discovered that companies which implemented innovation to improve their processes and differentiated their products were significantly ahead of their competition in terms of market share, profitability, companies' growth and net income. Lukes \& Stephan [14] found out that innovation was a key driver that could guarantee competitive advantage for organizations. They also confirmed that process of innovation related to generating and implementing new ideas, processes and procedures performed tasks in the best, most effective manner and offered the best products and services. Organizational innovation means creation or change in current business practices, structure and models. Organizational innovations comprise changes in the structure and processes of an organization due to the implementation of new managerial and working concepts and practices, such as the implementation of teamwork in production, supply chain management or quality management systems [8]. Nevertheless, the effects of product, process and organizational innovation must be considered separately. Recent studies disclosed that there was a complementarity in product, process and organizational innovation which are considered jointly by applying multivariate probity specification. Three innovation decisions to be made are thus independent. To benefit from these types of innovation, managers need to jointly exploit these different types of innovation activities and their potential synergies [19].

Outsourcing is an agreement in which one company contracts-out a part of existing internal activity to another company [16]. It is reported that outsourcing brings great many of benefits like cost savings, transformation of investment costs into operational costs, application of economy of scale, activities performed by purposefully trained employees, higher transparency in cost management, flexibility in the scope of services purchased, drop in workforce etc. [12]. The invested capital reduction comes from the more flexible assets, the reduction of labour costs, the reduction of waiting times and the reduction of waste [5] But in spite of this statement a systematic understanding of the financial consequences of business service outsourcing is missing [17]. According to Gartner Inc. (2005), more than 60 $\%$ of business services outsourcing arrangements fail and entail additional risks [11].

Servitization was proposed by Vandermerve and Rada [23]. Servitization is defined as a strategic innovation of an organization's capabilities and processes to shift from selling products to selling an integrated product and service offering that delivers value in use [15]. Especially maintenance services indicate the potential to create the value [24]. The goals of maintenance are derived from overreaching goals of the company. Derived maintenance targets are: (1) achieving required availability and reliability of production equipment; (2) effective use of maintenance resources [20]. It is expected clients' satisfaction can be fulfilled through the quality of maintenance providers 'service. After understanding the minds of their clients, the service providers can tailor-make their own business strategies for sustainable development. To enable this, it is important to set optimal outsourcing relationships between clients and maintenance service providers.

The change of contemporary enterprises to enterprises Industry 4.0 comes also with competitive advantage that the product can be produces individual for the respective customer. But there is a difference between big-sized companies and small and medium sized companies. Namely the smaller enterprises don't have as much money to invest for this change [18]. 
The Industry 4.0 philosophy has a multidiscipline character. Beside managerial and economic factors it is necessary to do right analyses of industrial and technological processes as well as to respect sociodemographic and personal limitations. Digitalisation of product's portfolios as well as digitalisation of services is regarded to be a key to sustainable success in business. Growing rate of digitalisation cause that more than $70 \%$ of contract works in services will be substituted by computers [2]. Economy of services will be stepwise changed into Economy of knowledge.

\section{Research questions and hypotheses:}

The following research questions were suggested to fill the existing gap within the literature [3]: (1) Why is it necessary to develop a normative model and how it can be implemented in the environment of enterprises turning in coming Industry 4.0 era? (2) What is the main motivation to specific organizational innovation adoption? (3) How can the normative model improve decision-making process in the firms' service processes?

Since the research was performed in parallel in three industrial sectors (production, service and trading sector), $\mathrm{H}_{0}$ hypothesis can be set up as follows: There are statistically significant differences in the perception of service innovation concerning outsourcing benefits among these three sectors.

\subsection{Research methods used}

The research is based on a comprehensive literature review [6] in the areas of management in Industry 4.0 era, organizational innovation in services, outsourcing strategy with respect to effectivity and performance. By use of existing contemporary literature review it was attempted to analyse system approaches which can be best applied normative model design. Because there is not shared understanding of Industry 4.0 access to the future role of the outsourcing strategies in reviewed resources, there was necessary to carry out critical analysis of the outputs and confront their applicability for specific purposes of this research.

In principle quantitative and qualitative research were given a priority. The process of the quantitative research itself consisted of three stages - preparation, implementation and check-up of the questionnaire. Within the preparation stage the aim of the research was defined and a specific questionnaire was drawn up. This questionnaire was piloted in practice and partially modified to be better understood by respondents. The stage of implementation included targeted distribution of questionnaires and communication with respondents. Respondents did not have any queries regarding the structure of the questionnaire or technical terms. In the final stage the completed questionnaires were evaluated and the gained results were commented on. The set objectives were met in this way.

The research was performed under the umbrella of the Czech Maintenance Union. To get the most reliable results, the combined approach comprising three research methods was used. The sample was subject to random selection. Questionnaires comprising 13 questions were distributed among maintenance managers and shift masters during purposefully organized professional trainings. The research covered period of 2016-2017 when six training sessions took place. Consequently 89 questionnaires were filled in and collected. Almost all the applicants who were subjected to the survey were willing to respond the questions posted in questionnaire. The response rate was thus almost quantitative. The responders came from three different business areas: industrial production, trading and services. To examine the differences in perception of outsourcing benefits within three groups of companies (production, service and trading sector), $\chi$-squared test was conducted. The factors with highest frequency of responses were then included into normative model. The survey was evaluated by means of simple statistics focused on frequency of responses.

Questionnaire survey was complemented on by semi-structured interviews conducted with selected managers and specialists. Contextual interviews were conducted with top, middle and first line managers and/or experts. In total, 17 interviews were conducted in companies operating in the three industrial sectors (production, service and trading sector). Such number of interviews is in consonance with Creswell's findings. Creswell considers 20-30 interviews sufficient [9]. Aas et al. [1] conducted 52 in-depth interviews with managers and employees involved in the area of new service development. The interview was completed the moment no new findings about the topic could be objectively obtained. The usual duration of each interview varied from 50 to 70 minutes. The aim of these interviews was to both to confirm and deepen conclusions which were obtained from questionnaire surveys and identify barriers to smooth implementation of outsourcing. For data processing, appropriate coding was used. The codes referred to key areas which were covered by interviews (the role of organizational innovation in company development, motivation to outsourcing, critical point to outsourcing, outsourcing performance measurement, risks of outsourcing, etc.). The interviews were usually conducted by the authors of the paper, which ensured an acceptable professional level of the interview. Based on Oliveira's recommendation, the framework of each interview was always planned (the interviewee, the scope of interviewing, the approaches to the analysis of information obtained, coding and the utilization of information in the following process). Contextual interviews reflect the following topics: (1) factors which managers consider conditional for decision-making on service outsourcing, (2) possible internal and external barriers to the smooth execution of outsourcing, (3) effective management of outsourcing process, (4) actual and potential benefits to be derived from service outsourcing and (5) risks of outsourcing solution. One of the main reasons for the execution of questionnaire survey and conducting interviews was to obtain underlying assumptions for the determination of decisionmaking criteria. 
The practical verification of the model was able on the chosen mid-sized company. Thus the use of a single case enabled greater depth for exploration. According to Yin [26], the study of a single firm may involve a number of different cases or units of analysis. In this way, this approach supported theory testing as well as theory refinement, which helped develop the understanding of new phenomena [25].

\section{Results ascertained by research techniques}

The questionnaire survey revealed that by all respondents, services innovations concerning outsourcing was in progress. Among the responders almost $60 \%$ companies operated in production sector, the rest was engaged in service or trading sector). $76 \%$ companies were ranked among big companies (more than 250 employees). $79 \%$ of responders considered outsourcing an important managerial technique which might be beneficial if implemented rationally. Companies are well familiarized with the concept of outsourcing and some of them either implemented outsourcing or contemplate outsourcing implementation. From this point of view $16 \%$ and $65 \%$ companies implemented partial and full and partial outsourcing respectively. The companies perceive the main benefits of maintenance outsourcing in cost savings (39\%), higher quality of services (30\%) and headcount decrease (31\%). According to semi-structured interviews company staff is quite knowledgeable about the factors which are contingent for smooth and successful outsourcing implementation. The most decisive factor which should be taken into consideration upon the decision on outsourcing should be risk of outsourcing $(65 \%)$, price to be paid for outsourcing $(60 \%)$, quality of delivered services (79\%), flexibility of service delivery (62\%) and contingency solving (51\%). Other unspecified factors accounted for $1 \%$. The factors with the highest frequency of responses were then chosen as key decision-making criteria. The main obstacle to smooth adoption of outsourcing rests in risks tied with outsourcing (65\%) and difficulties with the management of outsourcing relationship (35\%).

On the other hand, managers who oversee making decision about outsourcing lack proper decision-making tool which would consider all relevant parameters. Parameters like economic effectiveness, quality of services, flexibility of service delivery, contingencies solution or risk exposure were of superior importance for the responders. In addition, a bit less, important parameters like demandingness of outsourcing management or tight dependence on the outsourcer were also addressed.

In-depth interviews provided research team with insight into practical aspects of maintenance outsourcing. Interviewees confessed that the maintenance is directed to higher specialization where little room can be reserved to staff with general but non-specialized competences. The endorsed that outsourcing might be optimum solution to this problem because companies can contract for highly specialised services provided by external partners. They shared the opinion that services which are preformed periodically with low frequency or even randomly (e.g. apparatuses qualification or various technical tests) should be the candidates for outsourcing. As a matter of fact following information were extracted from the interviews: (1) decision making on service outsourcing is influenced by the willingness of the partner to create networks and share know-how, (2) company size and resources limitation are the most important internal barriers while political restrictions in global economy are often mentioned as external barriers, (3) building a value chain in business model involving both partners and customers are precondition for effective outsourcing management, (4) apart from better economic performance higher rate of flexibility, pressure on continuous innovation and faultless communication are often mentioned among service outsourcing benefits, (5) outsourcing must be incorporated into holistic risk management strategy (Enterprise Risk management - ERM).

\section{Normative decision-making model development}

The main goal of the paper was to develop normative decision-making model which would be generally applicable in firm's service processes. Done contextual interviews shoved the large expected innovation activities in coming Industry 4.0 philosophy were expected in outsourcing organization. In general, the development of the model reacted to the problems which consisted in both technical and economic suboptimum support service activities performance. The reason for lagging behind optimum service effectiveness was company orientation on its core business, non-core business being dropped. Very often the company missed both qualified employees and technical platform, which may lead to the loss of flexibility - one of the most demanded attribute in Industry 4.0 environment. Moreover, some activities were performed very rarely, and employees came to continuously lose knack and skills. From economic point of view, it often dealt with inefficiently performed activities where economy of scale was not utilizable.

Based on questionnaire survey evaluation and contextual interviews to be conducted with maintenance specialist and managers following five decision criteria were determined:

Economic criterion (expressed in terms of NPV of respective variant). Simple cost/benefit analysis is not applicable because it doesn't consider variability of cash flow during maintenance life cycle. One of the most important factors of cash flow variability is the conversion of investment costs into operation costs. It is inevitable to assess cash flows in a longer time since some cash flow have one-off character (investment procurement or severance pay) while other proceed continuously. Finally, the variant with highest NPV takes precedence over others. Because NPV is a cardinal variable it illustratively shows differences between shareholders' values added by individual variants. 
Service delivery flexibility reflects the ability of the provider to adjust the scope of the services to be provided on actual customer's demand.

Service quality and reproducibility refers to meeting 'voice of the customer' which rests in maintenance of high quality services over long time (unexpected increase/decrease in customer demand etc.).

Contingencies solution responds to provider's capability to solve various emergency which may occur during production process (production or facility crashes, natural disasters etc.).

Risks (tied with the variant) are inherent part in any decision-making process. A lot of attention should be therefore paid to risk assessment. Decision-makers must be explicit about the involvement of the risk into normative decisionmaking model. If the variants significantly differ in their risk profiles, then it is worth recommending to involve risk as one of decision criteria. If this is the case the risk is properly assessed by means of any risk analysis approaches (with advantage by risk matrix) and it shouldn't be incorporated as a risk increment to NPV. The risk tied with individual variant preferably refer to non-systematic risk (this risk is particular to one variant).

These criteria are recommended to be properly weighed so that the relevance of each criterion may be exactly determined. Any method of weights determination is applicable. Simple and user-friendly methods are worth recommending (typically 100 point's allocation, pair comparison, Fuller method etc.). Each criterion was assessed on the scale which ranked from 1 to 5 where 5 represented maximum value.

As a financial criterion Net Present Value (NPV) of the variant was chosen. Opting for NPV which represents the sum of discounted future cash flows obviates problems with time inconsistency between double-entry accounting and cash flow expressions of both cost and benefit items. NPV is then calculated by means of the formula posted in commonplace managerial literature [7]. Cardinal financial criterion NPV was then transformed to point scale:

$\operatorname{Scoring}_{N P V}=\frac{N P V_{\text {max }}}{N P V_{\text {variant }}} \times 5$

where: $N P V_{\max }$ is the highest Net Present Value NPV achieved during variant comparison

$N P V_{\text {variant }}$ is the Net Present Value of any variant taken into account

Needless to say that NPV calculated for any variant is always negative due to high predominance of cash outflows over cash inflows. The first prerequisite for NPV calculation was choosing maintenance life cycle. It was derived from the assumption that average top management tenure is roughly five years and during this period prevalent part of strategic decisions should prove their viability. That is why five-year maintenance life cycle was recommended as timeframe standard.

Another parameter which attracts attention in discounted cash flow models (DCF) is a discount rate. It is worth recommending to use company discount rate to be calculated as a weighted average of capital costs (WACC) or to use rate of return requested by shareholders. To facilitate calculation various approaches to the determination of equity costs were published in a scientific literature (modular models, $\mathrm{CAPM}^{1}$ ) [7]. Since the calculations of NPV for individual variants are intended for comparison purposes only this parameter is not as sensitive as in the calculation of usual investment project effectiveness. Qualitative like quantitative criteria are necessary to be transformed into measurable scale.

Typically, behavioural scale was used for the evaluation of non-financial criteria. Each "behavioural formula" which describes typical behaviour is assigned certain point score. Table 1 shows the example of scoring calculation for the parameter defined as service contingency solution. Scoring for the rest of parameters was obtained by the same way.

\begin{tabular}{|l|l|l|l|l|}
\hline \multicolumn{1}{|c|}{ Point score 1 } & \multicolumn{1}{|c|}{ Point score 2 } & Point score 3 & Point score 4 & \multicolumn{1}{c|}{ Point score 5 } \\
\hline $\begin{array}{l}\text { Neither does service } \\
\text { provider solve } \\
\text { contingencies nor is } \\
\begin{array}{l}\text { willing to assume any } \\
\text { obligation to solve } \\
\text { contingencies. }\end{array}\end{array}$ & $\begin{array}{l}\text { Service provider } \\
\text { solves problem only at } \\
\text { his discretion. He is } \\
\text { not willing to assume } \\
\text { any obligation in this } \\
\text { respect. }\end{array}$ & $\begin{array}{l}\text { Service provider } \\
\text { solves or is willing to } \\
\text { assume obligation to } \\
\text { solve problems at } \\
\text { clearly defined extent. } \\
\text { but in time which is } \\
\text { set by himself. }\end{array}$ & $\begin{array}{l}\text { Service provider } \\
\text { solves or is willing to } \\
\text { assume obligation to } \\
\text { solve any contingency } \\
\text { but in time which is } \\
\text { set by himself. }\end{array}$ & $\begin{array}{l}\text { Service provider } \\
\text { assume obligation to } \\
\text { solve any contingency } \\
\text { in mutually accepted } \\
\text { and agreed time. }\end{array}$ \\
\hline
\end{tabular}

Source: own

Table 1. Behavioural scale for scoring calculation of contingency solution

${ }^{1}$ Capital Assets Pricing Model 
Needles to stress that all unacceptable options should be excluded from the evaluation. Even if decision-maker himself must be explicit about the definition of unacceptable option, this model recommends excluding any option which is rated by the lowest point score in any decision-making criterion. Finally, the utility of each variant is calculated as expected value $\mathrm{E}(\mathrm{V})$ (weighted arithmetic mean):

$E(V)=\sum_{n=1}^{N} w_{n} \cdot P C R_{n}$

where: $w_{n}$ is weight of criterion $n$

$P C R_{n}$ is point score of criterion $n$

Eventually the variant with the highest utility shall be intended for implementation. The selection of the most suitable variant is thus substantiated from several points of view. Such a model offers wide range of flexibility which qualifies it for the adoption in various industrial branches.

\section{Case study as a tool for the model's validation}

The model was validated on the pattern of mid-sized Czech pharmaceutical company PharmaComm s.r.o. (further referred as the Company). The Company is focused on the development, production and distribution of active pharmaceutical substances intended for both human and veterinary use. The company operate highly sophisticated technology with a high level of automation. The company had to challenge continuous increase of maintenance costs which were closely tied with the ineffectiveness of maintenance services performance.

These costs prevalently originated in permanently increasing complexity of operation processes and stricter regulatory impositions. Basically, some of activities were performed irregularly or randomly which prevented Company from benefiting from economy of scale. Company assets dedicated to maintenance performance were partly unutilized. Until recently the Company has arranged for maintenance activities on its own (maintenance insourcing).

The Company established internal maintenance department which took charge of both preventive and regular maintenance. Company management decided to make use of purposefully developed normative decision-making model to decide about the most appropriate redesign of maintenance processes. Three strategies were considered for implementation:

- Maintenance insourcing (de facto retaining status quo) where the maintenance from organizational and authority point of view remains the part of the Company. The activities are executed by internal company employees who take care of the procurement of investments, material or spare parts. Notwithstanding maintenance insourcing the Company adhered in minimum extent to outsourcing of highly specialized activities. E.g. regular yearly functional control of analytical devices by authorised firms.

- Complete maintenance outsourcing where all the maintenance service delivery is transferred to external subject (general contractor). The company made 9 out of 10 maintenance workers redundant while maintenance manager was retained to manage outsourcing relationship. The company doesn't purchase investments any longer and transfer this activity to a general contractor.

- Maintenance outsourcing with reverse leasing of assets represented variant when the Company sold fixed assets which were operationally tied with maintenance to a contractor and made some earnings out of this deal. The outsourcer then proportionally incorporated these assets value to the maintenance service price. In general, the outsourcer provided the Company with requested maintenance service in the same way as in complete maintenance service outsourcing.

It is worth stressing, that variant development was fully at discretion of management team. Other possible variants might be outsourcing to more than one subject, partial outsourcing, outsourcing to company subsidiary etc. The weights of individual criteria were determined by the 100-points allocation method. Point score for each criterion was normalized to fit within $100 \%$ scale. Furthermore, each variant was subjected to critical evaluation based on criteria selected. Based on expert team discussion each variant was assigned point score ranking from 1 to 5 .

Decision-makers were maintenance manager, shift masters, ISO company specialist, operation manager and technician. The results of utility calculation for three considered variants of maintenance organizational arrangement are shown in table 2. 


\begin{tabular}{|c|c|c|c|c|c|c|}
\hline Criterion & 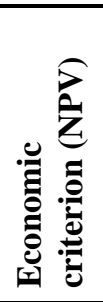 & 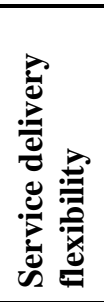 & 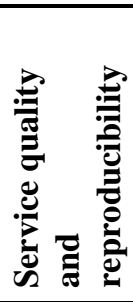 & 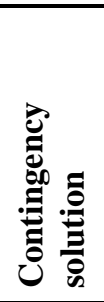 & 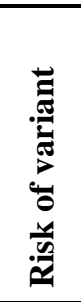 & 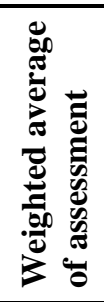 \\
\hline Weights in percentage & 62,0 & 5,2 & 19,8 & 3,0 & 10,0 & \\
\hline Insourcing & 4,7 & 3,8 & 4,2 & 3,9 & 4,9 & 4,55 \\
\hline Outsourcing & 5,0 & 4,3 & 4,5 & 4,2 & 3,9 & 4,73 \\
\hline Outsourcing with reverse leasing of assets & 4,9 & 4,3 & 4,5 & 4,2 & 3,9 & 4,66 \\
\hline
\end{tabular}

Source: own

Table 2. Calculation of utility of insourcing/outsourcing variants

Although there were no significant differences in weighted average of assessment, the partial evaluation of set criterion moved decision-makers to prefer the outsourcing strategy. This organizational innovation led to lean concept in service which enabled to be more flexible in leading processes. In this way business model became refined in order to improve distributed value chain. The company started to adopt smart processes using dynamic clusters with cooperating partners.

\section{Conclusions, discussions, limitations and the possibilities of further research}

The model was validated on the pattern of mid-sized pharmaceutical company which successfully decided about the adoption of maintenance outsourcing by means of the model in question. Decision-making process was executed by top management team which contributed to the verification of key standpoint which were crucial to the final decision. Conclusions of the research enabled to formulate responses to research questions:

(1) Why is it necessary to develop a normative model and how it can be implemented in the environment of enterprises turning in coming Industry 4.0 era? The use of a normative model as a standard managerial routine for decision-making procedures makes it possible to carry out such decision-making repeatedly. The environment Industry 4.0 is characterized by high level of flexibility accompanied by frequent changes. The normative model can help make innovation strategies as standard routine. If basic constraints are pre-defined, the results are comparable. Final evaluation is then more valuable. With regard to its practical application, the model is easy to master and is operable and integrable with the existing organization structure even if it follows strategy of Industry 4.0. (2) What is the main motivation to specific organizational innovation adoption? It was examined that the main motivation to the execution of specific organizational innovation (outsourcing) was cost savings, drop in headcount and enhancing flexibility of services delivered. Transformation of investment costs into operation costs implying better cash flow management surprisingly didn't attract much attention and was addressed in minority responses. (3) How can the normative model improve decision-making process in the firms' service processes? Normative model offers relatively simplistic solution which can facilitate and streamline decision-making process on outsourcing. Companies which consider service outsourcing one of the possible organizational solution can very quickly take the model as it is or make slight adjustments to criterial selection and thus adapt the model to particular company conditions.

The verification of the hypotheses set in this article, was statistically confirmed by $\chi$-squared test, which was used to determine if there were significant differences among response frequencies to question "Where do you see the main benefits of outsourcing?" which were provided by three main group of responders (production, service and trading sector). The chi-square statistic is 19.9819. The $\mathrm{p}$-value is 0.010405 . The result is significant at $\mathrm{p}<0.05$. The calculation of $\chi^{2}$

was performed according to formula:

$\chi^{2}=\sum_{i=1}^{k} \frac{\left(X_{i}-N p_{i}\right)^{2}}{N p_{i}}$

where: $\mathrm{Np}_{\mathrm{i}}$ are expected frequencies

$\mathrm{X}_{\mathrm{i}}$ are actual frequencies

$\mathrm{k}=6$

significance level is 0.05

The results are summarized in table 3 . 


\begin{tabular}{|c|c|c|c|c|c|c|}
\hline & Cost savings & Head count drop & $\begin{array}{c}\text { Performance } \\
\text { quality }\end{array}$ & Service flexibility & $\begin{array}{c}\text { Core business } \\
\text { focus }\end{array}$ & $\begin{array}{c}\text { Row } \\
\text { Totals }\end{array}$ \\
\hline $\begin{array}{c}\text { Trading } \\
\text { sector }\end{array}$ & $\begin{array}{c}60(51.84) \\
{[1.28]}\end{array}$ & $\begin{array}{c}40(37.34) \\
{[0.19]}\end{array}$ & $\begin{array}{c}60(65.26) \\
{[0.42]}\end{array}$ & $\begin{array}{c}30(33.72) \\
{[0.41]}\end{array}$ & $\begin{array}{c}50(51.84) \\
{[0.07]}\end{array}$ & 240 \\
\hline $\begin{array}{c}\text { Service } \\
\text { sector }\end{array}$ & $\begin{array}{c}47(50.55) \\
{[0.25]}\end{array}$ & $\begin{array}{c}27(36.41) \\
{[2.43]}\end{array}$ & $\begin{array}{c}60(63.63) \\
{[0.21]}\end{array}$ & $\begin{array}{c}33(32.87) \\
{[0.00]}\end{array}$ & $\begin{array}{c}67(50.55) \\
{[5.36]}\end{array}$ & 234 \\
\hline $\begin{array}{c}\text { Production } \\
\text { sector }\end{array}$ & $\begin{array}{c}36(40.61) \\
{[0.52]}\end{array}$ & $\begin{array}{c}36(29.25) \\
{[1.56]}\end{array}$ & $\begin{array}{c}60(51.12) \\
{[1.54]}\end{array}$ & $\begin{array}{c}30(26.41) \\
{[0.49]}\end{array}$ & $\begin{array}{c}26(40.61) \\
{[5.26]}\end{array}$ & 188 \\
\hline $\begin{array}{c}\text { Column } \\
\text { Totals }\end{array}$ & 143 & 103 & 180 & 93 & $\begin{array}{c}662 \\
143\end{array}$ & $\begin{array}{c}\text { (Grand } \\
\text { Total) }\end{array}$ \\
\hline
\end{tabular}

Source: own calculation

Table 3. Summary of $\chi$-squared test calculation

Table 3 provides the following information: the observed cell totals, (the expected cell totals) and [the chi-square statistic for each cell]. The calculation of $\chi$ squared test proved that there were statistically significant differences in the perception of outsourcing benefits among these three sectors. The results also showed that maintenance outsourcing was in some extent adopted by most of companies which were subjected to research.

The chi-square statistic is 19.9819 . The $\mathrm{p}$-value is 0.010405 . The result is significant at $\mathrm{p}<0.05$. Therefore the hypothesis $\mathrm{H}_{0}$ about the independence of input variables cannot be rejected.

Industry 4.0 involves three, not fully defined phenomena, which prevent create simple deterministic models that would simulate a future development of the Fourth Industrial revolution. These phenomena are: (1) universal digitization, (2) increasingly implemented disruptive technological innovations, (3) the achievement of such a developed machine that gain the ability to autonomous behaviour through the use of controlling artificial intelligence [10]. This statement delimits limitation of research. The normative model design responds to contemporary insight into Industry 4.0 concept. If there would be any other scenario of future development in examined sectors, it will be necessary to adjust the normative model itself. The second limitation is that the research was limited only on outsourcing activities. Thus its results are not generally adjustable to any service processes in the firm. It would be the topic for further research. Third the research was carried out on maintenance outsourcing. That's why it is limited to maintenance outsourcing. Nevertheless, the research can be easily expandable to complex service outsourcing.

The model presented and discussed in this paper is based on several criteria including quantitative value creation criterion (NPV). The rest of the set of criteria are qualitative criteria, mostly of behavioural character. From the logic point of view, the model is quite transparent and easy to be implemented. The model was validated on the pattern of mid-sized pharmaceutical company. The company in question pursued this model upon making decision on maintenance service outsourcing.

The main contribution of the model can be seen in theory refining and theory testing. The model proposed was validated on the pattern of mid-sized company and the conclusions both endorsed initial assumptions and refined existing theory. Both those steps led to better understanding and confirmation of new coherences.

Even if the model was elaborated for the sake of maintenance outsourcing the author assumes that the model is expandable to other areas of service outsourcing (facility management, fleet management, payroll accounting etc.). The authors also suppose, the model can be easily adapted to fit in with any services by the replacement of decision-making criteria and elaboration of behavioural scale for each newly established criterion. Future research should be aimed at verification of above mentioned assumptions as well as at the extension of the model to other outsourcing sectors, such as R \& D or production outsourcing.

\section{References}

[1] Aas, T. H., Breunig, K. J. \& Hydle, K. M. (2017). "Exploring New Service Portfolio Management", International Journal of Innovation Management, Vol. 21, No. 7, 2017, pp. 1-31., ISSN (print): 1363-9196, DOI: $10.1142 / \mathrm{S} 136391961750044 \mathrm{X}$

[2] acatech - Deutsche Akademie der Technikwissenschaften, (2016). Kompetenzentwicklungsstudie Industrie 4.0, Erste Ergebnisse und Schlussfolgerungen, April 2016.

[3] Alvesson, M. \& Sandberg, J. (2011). Generating Research Questions through Problematization, Academy of Management Review, Vol. 36, No. 2., 2011, pp. 247-271., ISSN 0363-7425, DOI 10.5465/AMR.2011.59330882.

[4] Bauer, W., Schlund, S., Marrenbach, D. \& Ganschar, O. (2014). Industrie 4.0 - Volkswirtschaftliches Potenzial für Deutschland, pp. 46.

[5] Blanchet, M. \& Rinn, T. (2016). The Industrie 4.0 Transition Quantified - How the fourth industrial revolution is reshuffling the economic, social and industrial model, Roland Berger GMBH, https://www.rolandberger.com/publications/publication pdf/roland berger industry 40 20160609.pdf, Accessed: 2018-08-18 
[6] Boote, D.N. \& Beile, P. (2005). „Scholars before Researchers: On the Centrality of the Dissertation Literature” Review in Research Preparation. Educational Researcher, Vol.334, No. 6, pp. 3-15.

[7] Brealey, R., Myers, S. \& Allen, F. (2013). Principles of Corporate Finance, 11th Edition, McGraw Hill. ISBN: 978-0071151450

[8] Bujidos-Casado; M., Navío-Marco, J. \& Rodrigo-Moya, B. (2017). Comparative Analysis of Organizational Innovation in European Firms, Proceedings of European Conference in Intellectual Capital, Kidmore End, 2006, Academic Conference International LTD, pp. 42-50.

[9] Creswell, J.W. (2007). Qualitative inquiry and research design: Choosing among five approaches (2nd ed.). Thousand Oaks, CA: Sage., ISBN: 978-1412995306

[10] Diana, F. (2015). Interview with Gerd Leonhard, Available from: https://frankdiana.files.worldpress.com/2015/01/disruptive-scenarios.jpg, Accessed: 2018-06-16

[11 Eggert, A., Böhm, E. \& Crammer, Ch. (2017). „Business service outsourcing in manufacturing firms: an event study“, Journal of Service Management, Vol. 28 No.3, 2017, pp. 476 - 498., ISSN: 1757-5818, DOI: 10.1108/JOSM-11-2016-0306.

[12] Greaver M. F. (1999). Strategic Outsourcing: A Structured Approach to Outsourcing Decisions and Initiatives. American Management Association.

[13] Lok, L.K. \& Baldry, D. (2015). "Facilities Management Outsourcing Relationships in the Higher Education Institutes", Facilities, Vol. 33 No. 13/14, 2015, pp. 818 - 848., ISSN: 0263-2772, DOI: 10.1108/F-05-2014-0043

[14] Lukes, M. \& Stephan, U. (2017). „Measuring employee innovation: a review of existing scales and the development of innovative behaviour and innovation support inventories across cultures“. International Journal of Entrepreneurial Behavioural \& Research, Vol. 23, pp. 136-158. ISSN: 1355-2554

[15] Martinez, V., Bastl, M., Kingston, J. \& Evans, S. (2010). "Challenges in transforming manufacturing organizations into product-service providers. Journal of Manufacturing Technology Management”, Vol. 2, No. 4, 2010, pp. 449-469., ISSN: 1741-038X, DOI: 10.1108/17410381011046571

[16] McCarthy, I. \& Anagnostou, A. (2004). „The impact of outsourcing on the transaction costs and boundaries of manufacturing“. International Journal of Production Economics, Vol. 88, No.1, 2004, pp. 61-71. ISSN: 09255273, DOI : 10.1016/S0925-5273(03)00183-X

[17] Ostrom, A.L., Parasuraman, A., Bowen, D.E., Patricio, L., Voss, C.A. \& Lemon, K. (2015). „Service research prioritiesin a rapidly changing context", Journal of Service Research, Vol. 18, No. 2, 2015, pp. 127 - 159., ISSN: 1094-6705 DOI: 10.1177/1094670515576315

[18] Papa, M.; Kaselautzke, D.; Radinger, T. \& Stuja, K. (2017). Development of a Safety Industry 4.0 Production Environment, Proceedings of the 28th DAAAM International Symposium, pp. 0981- 0987, B. Katalinic (Ed.), Published by DAAAM International, ISBN 978-3-902734-11-2, ISSN 1726-9679, Vienna, Austria, DOI: 10.2507/28th.daaam.proceedings.136

[19] Papalia, R.B., Bertarelli, S. \& Mancinelli, S. (2018). „Innovation, Complementarity, and exporting. Evidence from German manufacturing firms“, International Review of Applied Economics, Vol. 32, No. 1, 2018, pp. 3-38., ISSN 0269-2171

[20] Poór, P.; Kuchtová, N., \& Šimon, M. (2014). Machinery Maintenance as a Part of Facility Management, Proceedings of the 24th DAAAM International Symposium on Intelligent Manufacturing and Automation, 2013, pp. 1276- 1280, B. Katalinic (Ed.), Published by DAAAM International, ISBN 978-3-902734-11-2, ISSN 17269679, Vienna, Austria,

[21] Schwartz, P. (2012). Winning in an uncertain future through scenario planning, In: Delivering Tomorrow, Logistics 2050, A Scenario Study, Deutsche Post AG, Bonn

[22] Tidd, J., Bessant, J. \& Pavitt, K. (2005). Managing Innovation, 3rd edition, London, John Wiley \& Sons. ISBN 0470-09326-9

[23] Vandermermerve, S. \& Rada, J. (1988). Servitization of business: adding value by adding services, European Management Journal, Vol. 6, No. 4, 1988, pp. 314-324., ISSN: 0263-2373, DOI:10.1016/0263-2373(88)90033-3

[24] Vidalakis, C., Sun, M. \& Papa, A. (2013). "The quality and value of higher education facilities: a comparative study, Facilities, Vol. 31, No. 11/12., 2013, pp.489-504., ISSN: 0263-2772, DOI: 10.1108/F-10-2011-0087

[25] Voss, Ch., Johnson, M. \& Godsell, J. (2016). Case Research In: Research Methods for Operation Management, Karlsson, Ch. (Ed.) Routledge, New York, 2nd edition, pp. 165-197, ISBN 978-1-138-94542-5, New York

[26] Yin, R.K. (1994). Case Study Research, Beverly Hills Publication, CA, SAGE Publications., ISBN 9780803956629 